Article

\title{
Initial Rhodonia placenta Gene Expression in Acetylated Wood: Group-Wise Upregulation of Non-Enzymatic Oxidative Wood Degradation Genes Depending on the Treatment Level
}

\author{
Martina Kölle ${ }^{1, *}$, Rebecka Ringman ${ }^{2}$ and Annica Pilgård ${ }^{1,2}$ \\ 1 TUM School of Life Sciences Weihenstephan, Technical University of Munich, 85354 Freising, Germany; \\ annica.pilgard@ri.se \\ 2 RISE, Research Institutes of Sweden, Bioeceonmy, Box 857, 50115 Borås, Sweden; rebecka.ringman@ri.se \\ * Correspondence: koelle@hfm.tum.de
}

Received: 25 November 2019; Accepted: 5 December 2019; Published: 7 December 2019

\begin{abstract}
Acetylation has been shown to delay fungal decay, but the underlying mechanisms are poorly understood. Brown-rot fungi, such as Rhodonia placenta (Fr.) Niemelä, K.H. Larss. \& Schigel, degrade wood in two steps, i.e., oxidative depolymerization followed by secretion of hydrolytic enzymes. Since separating the two degradation steps has been proven challenging, a new sample design was applied to the task. The aim of this study was to compare the expression of 10 genes during the initial decay phase in wood and wood acetylated to three different weight percentage gains (WPG). The results showed that not all genes thought to play a role in initiating brown-rot decay are upregulated. Furthermore, the results indicate that $R$. placenta upregulates an increasing number of genes involved in the oxidative degradation phase with increasing WPG.
\end{abstract}

Keywords: brown-rot fungi; oxidative degradation; fenton degradation; acetylation; scots pine; Pinus sylvestris; Postia placenta

\section{Introduction}

Wood is an attractive building material that is biodegradable, renewable, stores carbon [1,2], and can serve as an alternative to concrete and steel due to its mechanical properties [3,4]. Biodegradability is a disadvantage when wood is used in outdoor construction [5,6], if no adequate preservative method is applied. Hence, wood protection is necessary to prolong the service life of wooden products made of nondurable wood. Traditionally, wood is treated with copper-based preservatives, however, ecological and health issues surrounding copper-based preservatives have led to restrictions and regulations [7-9]. An alternative approach to traditional preservatives is wood modification, which alters the properties of the wood to enhance its resistance to degradation [8]. Wood can be either physically (heat-treated wood) or chemically (for example wood acetylation and furfurylation) modified. Acetylation is a widely studied wood modification method [8,10-13]. During acetylation, hydroxyl groups in the wood are replaced by acetyl groups $[1,8]$, leading to reduced hygroscopicity and volumetric swelling which bulks the cell walls and reduces water absorption $[8,14-16]$. Several studies have found, that a weight percent gain (WPG) of $10 \%$ leads to limited decay inhibition, whereas a WPG of $20 \%$ significantly increases decay resistance [8,17-20].

The exact mechanisms behind the decay resistance in acetylated wood is not known. However, recent results indicate that diffusion of fungal depolymerizing agents through the wood cell wall may be inhibited due to decreased equilibrium moisture content [8,21-25]. Hunt et al. [26] reported a decreased diffusion of $\mathrm{K}^{+}$ions with an increasing level of acetylation, which supports the theory 
that acetylation inhibits diffusion of hydrolytic reductants due to moisture exclusion [25]. Zelinka et al. $[24,27,28]$ hypothesized in their studies that an interrupted moisture network inhibits diffusion. This conclusion was supported by Beck et al. [16], who characterized moisture in acetylated wood with low-field nuclear magnetic resonance relaxometry (LF-NMR).

Thirty-two percent of the described fungi in the world belong to the Basidiomycota [29]. Wood decaying fungi, belonging to the Basidiomycota, are filamentous fungi and can be divided into two groups, white-rot and brown-rot fungi [30-32]. However, because decay mechanisms are much more diverse than assumed, such a distinction may be too simplistic [33]. Although more species of white-rot fungi are known, approximately $80 \%$ of the wood decay fungi found in wooden constructions belong to the brown-rot subgroup [34-37]. Because of their preference for softwoods, brown-rot fungi are the main recyclers of lignocellulose in Northern Hemisphere coniferous forests, and decay associated with brown-rot is reportedly the most destructive type $[5,38,39]$. Brown-rot decay rapidly leads to significant strength loss through depolymerization of the cellulose and hemicellulose fractions through non-enzymatic oxidative degradation processes [40-44], followed by the secretion of hydrolyzing enzymes [44-46]. Zhang et al. found, in 2016, that the two decay phases are in fact spatially separated and that the presence of sugars solubilized during oxidative decay triggers the transition from oxidative to enzymatic degradation [47].

Brown-rot wood degradation has been studied mainly in the organism Gloeophyllum trabeum (Pers.) Murrill and verified to some degree in Rhodonia placenta (Fr.) Niemelä, K.H. Larss. \& Schigel (also known as Postia placenta), Coniophora puteana (Schumach.) P. Karst., and Serpula lacrymans (Wulfen) J. Schröt. The details regarding the non-enzymatic oxidative degradation phase still remains unknown. The current theory is that during decay brown-rot fungi secrete oxalic acid, which diffuses into the lumen, where it functions as a chelator to sequester $\mathrm{Fe}^{3+}[46,48,49]$. $\mathrm{Fe}^{2+}$ is formed through reduction by hydroquinones, and $\mathrm{H}_{2} \mathrm{O}_{2}$ is believed to be formed through a reaction between hydroquinones and oxygen $[50,51]$. Hydrogen peroxide and $\mathrm{Fe}^{2+}$ react to hydroxyl radicals, which polymerize cellulose and hemicellulose, and modifies lignin [45,46,52]. This process solubilizes sugars, which can diffuse through the cell walls into the lumen, to become accessible to cellulases and hemicellulases [42,53].

Zhang et al. [47] found that thirty-three genes likely associated with redox processes were upregulated during early stages of decay, and 21 of them may be involved in generating $\mathrm{H}_{2} \mathrm{O}_{2}$ and $\mathrm{Fe}^{2+}$. Martinez et al. [54] identified a putative quinone reductase in $R$. placenta that is believed to recover iron reductants (hydroquinones) [50,54-56] and is also putatively mediating the reduction of iron chelators (oxalic acid) [55]. R. placenta has only one quinone reductase (QRD Pp1124517), compared with the two in Gloeophyllum trabeum, which have been shown to have different functions; one is involved in wood degradation and the other in stress defense [57]. R. placenta quinone reductase belongs to the Carbohydrate-Active enZYmes (CAZy) family AA6 and is likely involved in oxidative processes and the formation of intracellular enzymes for fungal protection. Mueckler et al. [58] suggested that Ppl44553 is a quinate transporter (PQT), belonging to the major facilitator superfamily domain. This domain includes sugar transporters, which bind and transport a variety of carbohydrates, organic alcohols, and acids. A major part of this family catalyzes sugar transport [59]. The exact function of the R. placenta PQT remains unclear. Laccases appears to play an important role by oxidizing methoxyhydroquinones into semiquinones that reduce $\mathrm{Fe}^{2+}$ [60] and are believed to be effective producers of $\mathrm{H}_{2} \mathrm{O}_{2}$ [61] . Four putative laccases have been found in $R$. placenta [54] and one of them is included in this present study (Lac1 Ppl111314). Extracellular $\mathrm{H}_{2} \mathrm{O}_{2}$ has also been suggested to be produced by copper radical oxidases (Cro), gluco-oligosaccharide oxidases, and glucose-methanol-choline (GMC) oxidoreductases, including alcohol oxidases (AlOx) and glucose oxidases (GOx) [54,62,63]. Alcohol oxidase is upregulated in the presence of cellulose and wood [38,54]. R. placenta has three genes encoding alcohol oxidases, belonging to the CAZy family AA3, AlOx1 Ppl44331, AlOx2 Pp1129158, and AlOx3 Ppl118723. Copper radical oxidase (Cro1 Ppl56703) belongs to the CAZy family AA5. Cro1, together with glucose oxidase 2 (GOx2 Ppl108489), are oxidoreductases involved in the $\mathrm{H}_{2} \mathrm{O}_{2}$ production [47]. Brown-rot fungi accumulate significant amounts of oxalic acid, which has been shown 
to be involved in their wood decaying system [64]. Oxaloacetate dehydrogenase (CyOx Ppl112832) is presumed to be involved in oxalic acid synthesis, which is important for sequestering and reducing $\mathrm{Fe}^{3+}$ to $\mathrm{Fe}^{2+}$ [13]. Glyoxylate dehydroxygenase (GlyD Ppl121561) is likely involved in oxalic acid synthesis, by catalyzing the production of oxalate through oxidation of glyoxalate [65]. It is also involved in the glyoxylate cycle [66]. Munir et al. [66,67] purified a GlyD that catalyzes dehydrogenation of glyoxylate to oxalate in the presence of cytochrome c. Munir et al. [66] also found that GlyD exhibited a strong correlation with the biosynthesis of oxalic acid and fungal growth.

Previous studies (mostly on R. placenta) have shown that brown-rot fungi are not killed when growing on acetylated wood and can express genes needed for both the non-enzymatic oxidative degradation process and the enzymatic wood degradation process [11,13,68-70]. Even though the fungi express the genes needed for degradation, the wood remains intact for a prolonged period of time as compared with untreated wood materials. Since the fungi express genes involved in wood degradation in modified wood, before mass loss occurs, at similar levels as in untreated wood where degradation has begun, it is clearly shown that the fungi are attempting to degrade the wood but fail [11,13,69-71]. Despite previous research, it is still not known which regulatory mechanisms in the brown-rot degradation machinery are prevalent during degradation of acetylated wood. In order to improve the decay resistance of acetylated wood, it is of crucial importance to understand the decay mechanisms of incipient decay.

To investigate and improve wood modification methods, degradation tests are often used, for example, the miniblock test [72]. Rhodonia placenta (Fr.) M.J. Larsen \& Lombard is used as a model fungus for standardized degradation tests in Europe (FPRL280) and the USA (MAD-698R) (AWPA E10-16, 1991; EN 113, 1996). Previous comparisons of gene expression when growing on untreated and modified wood supply hints on fungal behavior $[11,24,25,73]$. Most studies used only a small number of biological replicates and often encountered difficulties differentiating the non-enzymatic oxidative degradation phase from the enzymatic degradation phase. Zhang et al. presented in 2016 a method making it possible to separate the two phases. They used wood wafers (with the largest area being the cross-section) placed in an upward position on previously inoculated feeder strips. Fungi were allowed to grow up along the wafers forming a clear hyphal front. This method has previously never been used on modified wood.

The aim of this study was to investigate the differences in gene expression of 10 different genes in $R$. placenta during the non-enzymatic oxidative degradation phase, when grown on wafers of untreated wood and wood acetylated to three different levels.

\section{Material and Methods}

\subsection{Wood Samples}

Wood boards from Scots pine sapwood (Pinus sylvestris L.) were cut into wafers $\left(80 \times 18 \times 2.5 \mathrm{~mm}^{3}\right)$, with the largest area being the cross section [74]. The samples were dried at $103{ }^{\circ} \mathrm{C}$ for $24 \mathrm{~h}$ and their dry weights were determined. Dried wafers were acetylated for $15 \mathrm{~min}, 30 \mathrm{~min}$, and $60 \mathrm{~min}$ to achieve three different acetylation levels; 10 (AC10), 15 (AC15), and 20 (AC20) weight percent gain (WPG) (Table 1). Then, 50 samples (only 25 for AC10) were put in a glass flask (1 L) and a vacuum was attached for $30 \mathrm{~min}$. Then, $50 \mathrm{~mL}$ of acetic anhydride was injected, followed by $50 \mathrm{~mL}$ of pyridine. After vacuuming for another minute, the samples were incubated at room temperature for $3 \mathrm{~h}$, followed by lowering the flask into an $80^{\circ} \mathrm{C}$ water bath for the corresponding reaction time. The reaction was stopped by washing the samples twice with ice-cold acetone and twice with an acetone-water mixture with a ratio of 1:1. Samples were rinsed in distilled water several times for 3 days, vacuum-impregnated with water, to remove all accessible chemicals, and dried again before the weight gain was measured. All samples were packed and autoclaved before the decay test. 
Table 1. Mean weight percent gain (WPG) and standard deviation of the wood samples.

\begin{tabular}{cc}
\hline Mean WPG & Standard Deviation \\
\hline $\mathbf{1 0}$ & 0.18 \\
$\mathbf{1 5}$ & 0.13 \\
$\mathbf{2 0}$ & 0.14 \\
\hline
\end{tabular}

\subsection{Decay Test}

R. placenta FPRL 280 (Fr.) was used for the decay test previously described by Zhang et al. [47]. As growth medium, $50 \mathrm{~g}$ of soil, $25 \mathrm{~g}$ of sand, $20 \mathrm{~g}$ of vermiculite, and $45 \mathrm{~mL}$ of water were mixed for each specimen container. The jars were autoclaved. Feeder strips of $P$. sylvestris sapwood were autoclaved, and three per glass were placed on the soil medium and inoculated with agar plugs from pregrown $4 \%$ malt agar plates. For each treatment, untreated (UT), 10\% acetylated (AC10), $15 \%$ acetylated (AC15), and $20 \%$ acetylated (AC20), 16 glasses $(n=16)$ with three samples each were prepared. After the feeder strips were completely overgrown, one wood wafer was placed on each feeder strip. The jars were stored in a climate chamber at $22{ }^{\circ} \mathrm{C}$ and $70 \%$ relative humidity. Samples were harvested according to the height of the hyphal front ( $3 / 4$ of the wood wafer overgrown). Only samples with even hyphal growth, around the whole sample, were included in the test. Since the cross section was the largest area, the mycelia growing up the sample could easily grow into the sample through the wood cell lumen. With this sample design, it was possible to assure that the fungi had reached the same level inside the sample as outside the sample [47]. Sections with a size of five millimeters, including the hyphal front, were cut out of the wafers, immediately frozen in liquid nitrogen and stored at $-80^{\circ} \mathrm{C}$ awaiting further analysis. The section size was chosen due to an expected growth rates of about $2.5 \mathrm{~mm} /$ day, with the first $5 \mathrm{~mm}$ representing approximately a $48 \mathrm{~h}$ window, during which the non-enzymatic degradation phase has been shown to take place [47]. Additional tests were done to obtain data on mass loss and growth rates for all treatments. For these tests a different set of samples was used.

\subsection{RNA Purification and cDNA Synthesis}

All $5 \mathrm{~mm}$ sections from one jar (three samples) were pooled into one biological replicate. A Mixer Mill MM 400 (Retsch GmbH, Haan, Germany) using one $1.5 \mathrm{~cm}$ steel ball and $30 \mathrm{~Hz}$ for 2 min was used to produce wood powder. Containers, beads, and samples were frozen with liquid nitrogen. Sixty milligrams of each sample were taken for RNA purification. Total RNA was extracted using a MasterPureTM RNA Purification Kit (Lucigen, Middleton, USA) [24]. RNA was converted to cDNA using TaqMan Reverse Transcription Reagents using Oligo d(T)16 (Applied Biosystems, Foster City, USA) with 10 times the standard dNTP concentration.

\subsection{Quantitative Real-Time Polymerase Chain Reaction}

A rotor-gene SYBRGreen polymerase chain reaction (PCR) kit (Qiagen, Hilden, Germany) was used according to the manufacturer's protocol for quantitative real-time PCR. Each sample was run with three technical replicates. $\beta$-tubulin was used as an endogenous control [13]. A list with all used primers including the number of the Joint Genome Institute (JGI) can be found in Table 2. The ten genes used in this study were chosen because of their assumed importance during the non-enzymatic degradation phase. This selection was based on previous findings $[11,13,47,68-70,75-79]$. Most importantly, the ten genes included in this paper have never been studied with this sample design before. Rotor-gene Q series software (Version 2.3.1, Qiagen, Hilden, Germany) was used to evaluate the runs. Expression levels for each technical replicate of the target genes (Tg) were calculated and normalized to the endogenous control according to the formula [80]:

$$
\text { Expression level }=10^{4} \times 2^{\mathrm{C}_{\mathrm{t}} \beta \mathrm{t}-\mathrm{C}_{\mathrm{t}} \mathrm{Tg}}
$$


Table 2. Primer sequences and JGI number of the target genes.

\begin{tabular}{|c|c|c|}
\hline Gene & JGI no. & Primer Sequence \\
\hline$\beta$-tubulin (bT) & 113871 & $\begin{array}{l}\text { CAGGATCTTGTCGCCGAGTAC/ } \\
\text { CСTCATACTCGCCСТCСТCTT }\end{array}$ \\
\hline Quinone oxidoreductase (QRD) & 124517 & $\begin{array}{c}\text { CGACGACAAGCCCAACAAG/ } \\
\text { GATGACGATGATGGCGATTTTAGG }\end{array}$ \\
\hline Alcohol oxidase 1 (AlOx1) & 44331 & $\begin{array}{l}\text { GGAGGTACAGACGGACGAAC/ } \\
\text { AGAGTCGACGACACCGTTCT }\end{array}$ \\
\hline Alcohol oxidase 2 (AlOx2) & 129158 & $\begin{array}{l}\text { TACTCGACGGCCCTCACTAT/ } \\
\text { CCGCTTGAGACTGAACACTG }\end{array}$ \\
\hline Alcohol oxidase 3 (AlOx3) & 118723 & $\begin{array}{l}\text { ACACCAAGGAGGACGACGAG/ } \\
\text { GACGAGCAAGGCAGACGAGTA }\end{array}$ \\
\hline Putative quinate transporter (PQT) & 44553 & $\begin{array}{l}\text { ACTGACCTTTTGCGCAGACT/ } \\
\text { CAATGTTGATTGTGGCGAAC }\end{array}$ \\
\hline Laccase (Lac) & 111314 & $\begin{array}{l}\text { CGGTGCTCTTGGCCACTTAG/ } \\
\text { CCATTGGTTATGGGCAGCTC }\end{array}$ \\
\hline Copper radical oxidase (Cro1) & 56703 & $\begin{array}{l}\text { CCTACCAGCTGCTTCCTGAC/ } \\
\text { AACGTTCGGCTGTATGAACC }\end{array}$ \\
\hline Glucose oxidase (GOx2) & 108489 & $\begin{array}{l}\text { GTCCGCTCTAACGTTGCTTC/ } \\
\text { CCGGCGTTATTGGAGAGATA }\end{array}$ \\
\hline Glyoxylate dehydrogenase (GlyD) & 121561 & $\begin{array}{l}\text { CGGAGCTGGACCTTTGTTAC/ } \\
\text { GCGCGAAGGCAAATCTAATA }\end{array}$ \\
\hline Oxaloacetate dehydrogenase (CyOx) & 112832 & $\begin{array}{l}\text { AAGGCGTTCTTCGAGGTCAT/ } \\
\text { AAAGCAGCAACCCGAGAAG }\end{array}$ \\
\hline
\end{tabular}

A mean concentration was calculated for each sample $(n=11-16)$ and normalized. Significance $(p<0.05)$ was calculated using the Student's $t$-test. Expression levels of the four different treatment levels (UT, AC10, AC15 and AC20) were compared.

\subsection{Statistical Evaluation}

A simple linear regression in Excel (Version 2016) was constructed for each of the four treatments for growth rate calculations.

\section{Results}

\subsection{Mass Loss and Growth Rates}

Average mass loss data and linear regression values of the growth test for all treatments are supplied in Table 3. Significantly lower mass loss was found in treated samples as compared with that in untreated samples. In AC20, a negative mass loss was detected.

Table 3. Mass loss and growth rates of all treatments during the period of colonizing the wood wafers.

\begin{tabular}{cccc}
\hline Treatment & Mass Loss $(\mathbf{\%})$ & Growth Rate $[\mathbf{m m} /$ day $]$ & Growth Rate $\mathbf{R}^{\mathbf{2}}$ Values \\
\hline untreated & 9.36 & 0.23 & 0.9955 \\
$\mathbf{1 0} \%$ acetylated & 1.63 & 0.24 & 0.9955 \\
$\mathbf{1 5 \%}$ acetylated & 0.25 & 0.22 & 0.91 \\
$\mathbf{2 0} \%$ acetylated & -0.16 & 0.25 & 0.9897 \\
\hline
\end{tabular}

The growth rates of $R$. placenta growing on untreated samples, as well as on acetylated samples, can be seen in Table 3. These correlate well with the findings of Zhang et al. (2016) [47]. However, 
R. placenta growing on AC15 behaved differently with a slower and more uneven growth rate as compared with the other acetylation levels.

\subsection{Expression of Target Genes}

\subsubsection{Upregulated Genes}

The results of all upregulated genes can be found in detail in Figure 1. Note that the figure shows logarithmic values and that the $y$-axis scale varies between the different genes.

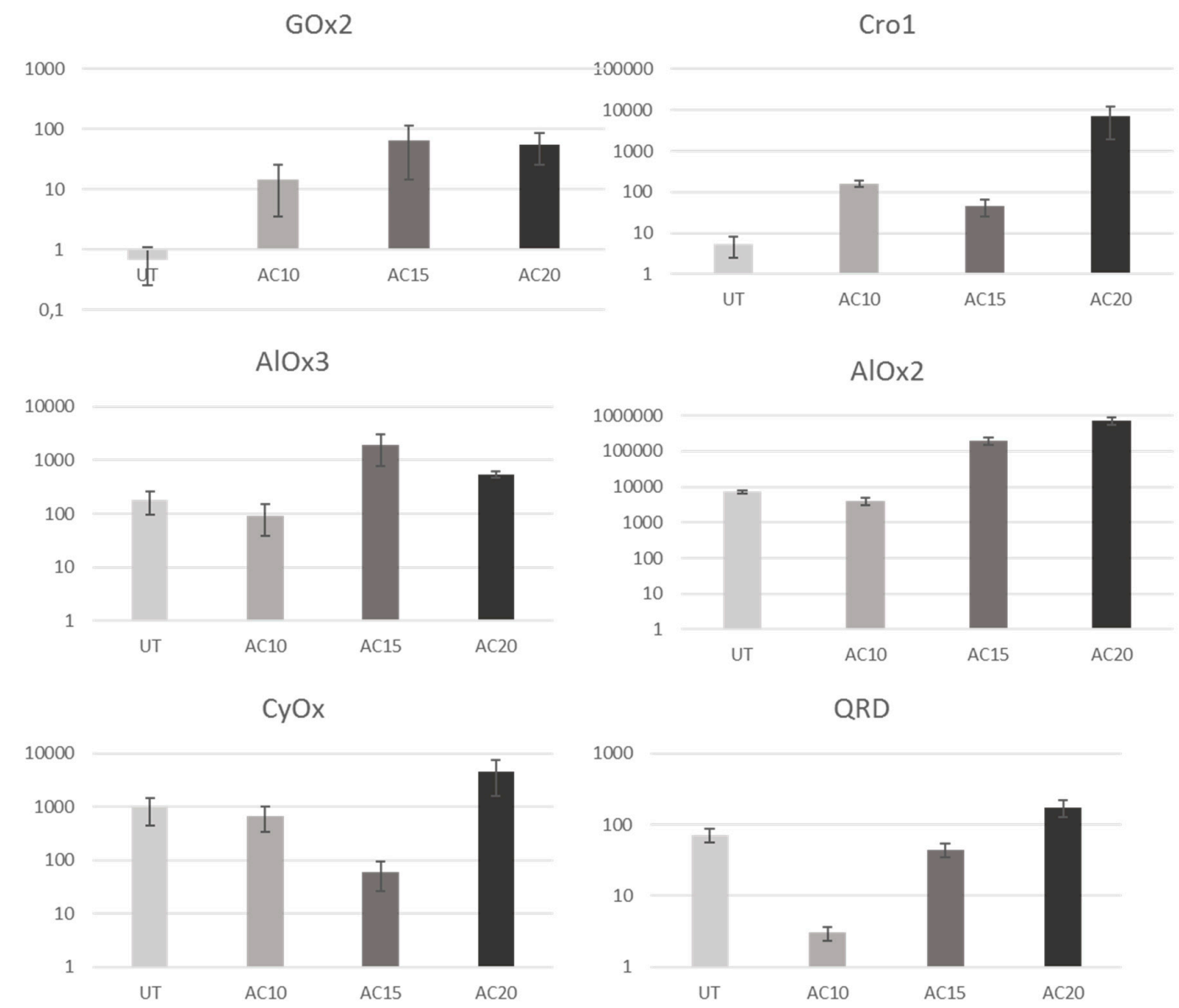

Figure 1. Logarithmic values for gene expression for upregulated genes (UT, untreated; AC10, 10 WPG acetylated; AC15, 15 WPG acetylated; and AC20, 20 WPG acetylated samples; GOx2, glucose oxidase 2; Cro1, copper radical oxidase 1; AlOx3 \& AlOx2, alcohol oxidases 2 \& 3; CyOx, oxaloacetate dehydrogenase; QRD, quinone oxidoreductase).

Expression levels for $\mathrm{AlOx} 2$ on acetylated samples were significantly upregulated as were those for $\mathrm{AlOx3}$ (except for AC10) as compared with those on untreated samples. For Cro1, all gene expression levels were upregulated in modified samples as compared with those in untreated samples, with an extreme upregulation seen in the AC20 samples. All treatments showed highly significant differences in gene expression for $\mathrm{CyOx}$ as compared with each other, except for the untreated samples as compared with the AC10 samples. The AC15 samples showed the lowest levels of CyOx expression, whereas expression was clearly upregulated in AC20 samples. Upregulation of GOx2 was unambiguous when comparing treated samples with untreated samples. AC15 and AC20 did not differ significantly for this gene, but all other treatments showed highly significant differences. Differences in gene expression of QRD were highly significant between all treatments. A clear upregulation of QRD was not found 
when comparing treated and untreated samples, although a strong upregulation in samples with high acetylation was observed.

\subsubsection{Downregulated Genes}

Figure 2 illustrates the results for all genes that were downregulated in treated samples as compared with those in untreated samples. As well, Figure 1 shows the logarithmic values and the $y$-axis scale differs between the genes. Lac1 showed the highest expression levels among untreated samples as compared with all treated samples. The lowest values were observed in AC10, increasing with increased intensity of acetylation. PQT was clearly downregulated in all three acetylation levels as compared with the untreated samples. Results for AlOx1 showed no significant differences between untreated and AC15 samples. AC10 and AC20 showed highly significant lower levels of gene expression as compared the untreated samples. Highly significant differences were also revealed for expression levels of GlyD in all sample treatments. All treated samples had lower expression rates for GlyD as compared with the untreated samples.
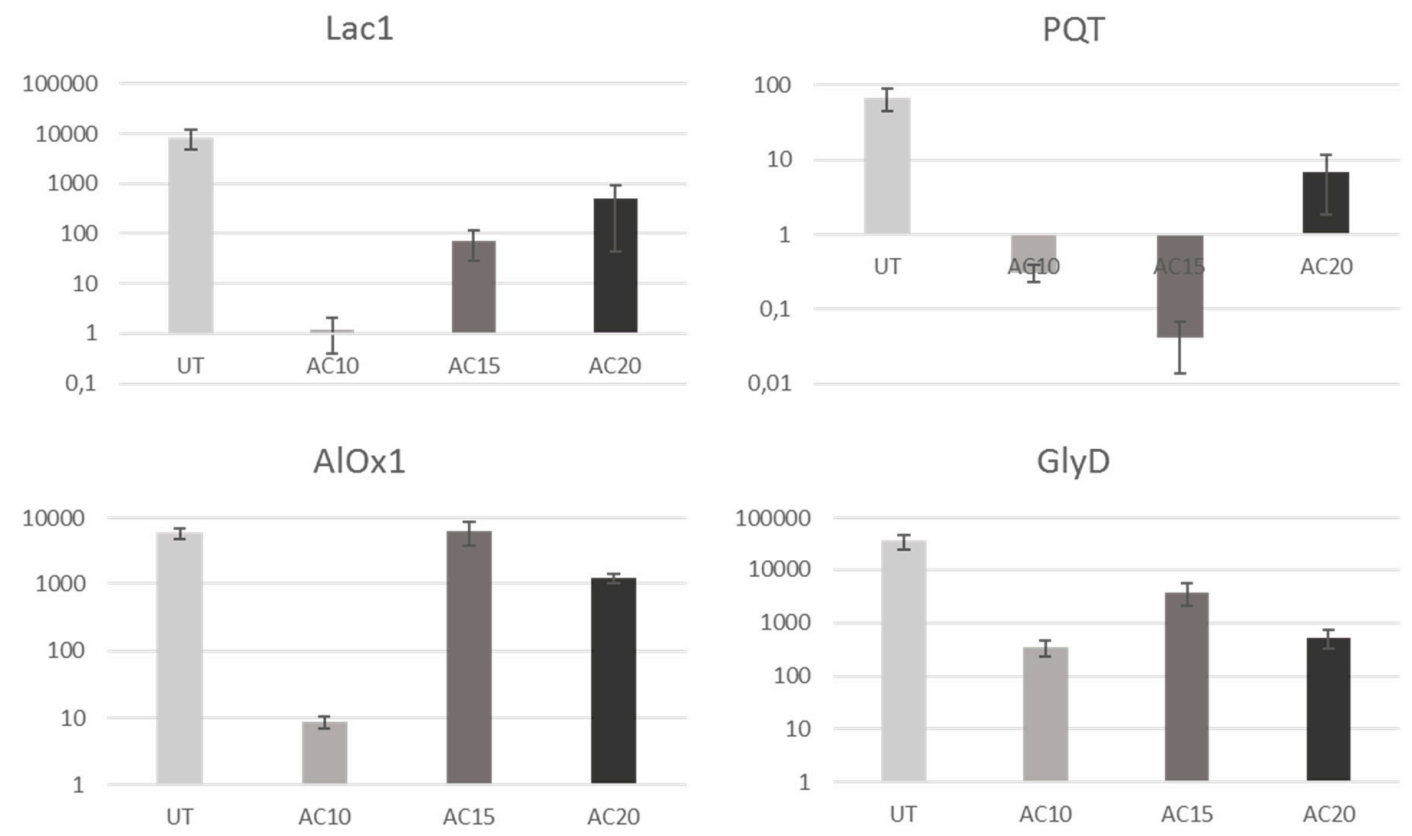

Figure 2. Logarithmic values for gene expression for downregulated genes (UT, untreated; AC10, 10 WPG acetylated; AC15, 15 WPG acetylated; and AC20, 20 WPG acetylated samples; Lac1, laccase 1; PQT, putative quinate transporter; $\mathrm{AlOx1}$, alcohol oxidase 1; GlyD, glyoxylate dehydrogenase).

\subsubsection{Effect of Acetylation on Overall Gene Expression}

For all genes, significant differences were found between treatments, except in three cases (AlOx1: UT-AC15; CyOx: UT-AC10; and GOx2: AC15-AC20) (Table 4). When UT and AC10 samples were compared, upregulation was observed for only two genes, Cro1 and GOx2, which are likely involved in $\mathrm{H}_{2} \mathrm{O}_{2}$-production. The comparison of untreated samples with $\mathrm{AC} 15$ showned an upregulation of $\mathrm{Cro1}, \mathrm{GO} 2$ and, additionally, $\mathrm{AlO} \times 2$ and $\mathrm{AlO} 33$ were seen. $\mathrm{AlOx} 2$ and $\mathrm{AlOx} 3$ are also thought to be involved in the production of $\mathrm{H}_{2} \mathrm{O}_{2}$. The same four genes were also upregulated in the AC20 samples. In addition to those, an upregulation was also seen for CyOx and QRD, which are involved in $\mathrm{Fe}^{2+}$ supply for the Fenton reaction. 
Table 4. $P$-values for all genes and treatments calculated with t-test. $P$-values are "not significant" for $p>0.05$; "significant" for $0.05 \geq p<0.01$, and highly significant for $p \leq 0.01$. Genes in bold are upregulated, others are downregulated.

\begin{tabular}{|c|c|c|c|c|}
\hline & AC10 & AC15 & AC20 & Gene \\
\hline UT & $2.08 \times 10^{-9}$ & $7.33 \times 10^{-9}$ & \multirow{3}{*}{$\begin{array}{l}2.27 \times 10^{-9} \\
9.81 \times 10^{-9} \\
1.14 \times 10^{-5}\end{array}$} & \multirow{3}{*}{ GlyD } \\
\hline $\mathrm{AC} 10$ & & $7.3 \times 10^{-6}$ & & \\
\hline AC15 & & & & \\
\hline UT & $3.60 \times 10^{-5}$ & $5.85 \times 10^{-4}$ & $4.07 \times 10^{-5}$ & \multirow{3}{*}{ GOx2 } \\
\hline AC10 & & $3.48 \times 10^{-4}$ & $5.19 \times 10^{-4}$ & \\
\hline AC15 & & & $1.37 \times 10^{-1}$ & \\
\hline UT & $1.29 \times 10^{-1}$ & $3.14 \times 10^{-6}$ & $4.03 \times 10^{-4}$ & \multirow{3}{*}{$\mathrm{CyOx}$} \\
\hline AC10 & & $3.16 \times 10^{-6}$ & $2.21 \times 10^{-4}$ & \\
\hline AC15 & & & $4.53 \times 10^{-5}$ & \\
\hline UT & $8.95 \times 10^{-9}$ & $3.26 \times 10^{-6}$ & $1.50 \times 10^{-4}$ & \multirow{3}{*}{ Cro1 } \\
\hline AC10 & & $9.69 \times 10^{-9}$ & $1.88 \times 10^{-4}$ & \\
\hline AC15 & & & $1.60 \times 10^{-4}$ & \\
\hline UT & $5.64 \times 10^{-7}$ & $6.44 \times 10^{-7}$ & $1.21 \times 10^{-6}$ & \multirow{3}{*}{ Lac1 } \\
\hline AC10 & & $7.38 \times 10^{-6}$ & $3.18 \times 10^{-4}$ & \\
\hline AC15 & & & $1.41 \times 10^{-3}$ & \\
\hline UT & $1.32 \times 10^{-6}$ & $1.26 \times 10^{-6}$ & $3.13 \times 10^{-6}$ & \multirow{3}{*}{ PQT } \\
\hline AC10 & & $2.25 \times 10^{-7}$ & $6.08 \times 10^{-4}$ & \\
\hline AC15 & & & $4.23 \times 10^{-4}$ & \\
\hline UT & $7.86 \times 10^{-3}$ & $7.71 \times 10^{-5}$ & $1.19 \times 10^{-12}$ & \multirow{3}{*}{$\mathrm{A} 10 \times 3$} \\
\hline $\mathrm{AC} 10$ & & $5.48 \times 10^{-5}$ & $3.75 \times 10^{-14}$ & \\
\hline AC15 & & & $5.32 \times 10^{-4}$ & \\
\hline UT & $4.70 \times 10^{-11}$ & $1.59 \times 10^{-10}$ & $3.72 \times 10^{-10}$ & \multirow{3}{*}{$\mathrm{A} 1 \mathrm{O} \times 2$} \\
\hline AC10 & & $1.24 \times 10^{-10}$ & $3.51 \times 10^{-10}$ & \\
\hline $\mathrm{AC} 15$ & & & $7.04 \times 10^{-9}$ & \\
\hline UT & $1.83 \times 10^{-12}$ & $3.5 \times 10^{-1}$ & $1.71 \times 10^{-11}$ & \multirow{3}{*}{$\mathrm{AlOx} 1$} \\
\hline AC10 & & $1.39 \times 10^{-8}$ & $6.56 \times 10^{-12}$ & \\
\hline AC15 & & & $1.63 \times 10^{-7}$ & \\
\hline $\mathrm{UT}$ & $1.26 \times 10^{-11}$ & $4.99 \times 10^{-6}$ & $3.48 \times 10^{-8}$ & \multirow{3}{*}{ QRD } \\
\hline AC10 & & $1.79 \times 10^{-8}$ & $1.52 \times 10^{-10}$ & \\
\hline AC15 & & & $2.27 \times 10^{-9}$ & \\
\hline \multicolumn{2}{|c|}{ Highly significant } & Significant & \multicolumn{2}{|c|}{ Not significant } \\
\hline
\end{tabular}

\section{Discussion}

\subsection{Mass Loss and Growth Rates}

The negative value for the mass loss in AC20 samples could be due to the weight gain through fungal hyphae. This phenomenon has been seen in previous studies $[71,77,81]$.

\subsection{Expression of Target Genes}

\subsubsection{Upregulated Genes}

The results of this study show that $R$. placenta upregulates parts of the genes involved in non-enzymatic oxidative degradation when growing on acetylated samples as compared with untreated wood, especially on higher levels of acetylation. An upregulation of GOx2 on acetylated samples was clearly shown as compared with untreated wood (Figure 1). GOx2 belongs to the GMC oxidoreductases, just as AlOx3. Ringman et al. [76] did not find any significant differences between untreated and modified samples for GOx2 expression which differs from our findings. This might be explained by the different sample design and that not only the non-enzymatic degradation phase was captured in the samples from Ringman et al. [76]. An upregulation in treated samples may be of importance for production of higher amounts of $\mathrm{H}_{2} \mathrm{O}_{2}$ for the Fenton reaction. 
The highest levels of Cro1 were found in AC20 samples, but no clear upward trend was observed with increasing acetylation level. An upregulation of Cro1 and GOx2 appeared already in the AC10 samples. This differs from the upregulation of AlOx2 and AlOx3 which were lower in AC10 samples as compared with untreated samples. The reason for the upregulation of Cro1 could be that the fungus increases the $\mathrm{H}_{2} \mathrm{O}_{2}$ production. Maybe the fungus can upregulate Cro1 and GOx2 faster and with lower effort than the two AlOx genes. Beck et al. [13] found a significant upregulation in samples with a WPG of 21 during initial decay as compared with other treatments, which supports our findings, but the values were higher in the present study. In the study by Ringman et al. [76], Cro1 levels were significantly lower in acetylated samples which is contrary to our findings for all acetylation levels. It should, however, be noted that the sample and experiment design differ between these studies. In Beck et al. [13] and Ringman et al. [76] the samples may have contained mycelia that were in both the non-enzymatic and in the enzymatic phase.

$\mathrm{AlOx} 2$ and AlOx3 are both significantly upregulated in AC15 and AC20 samples as compared with untreated samples. Alfredsen et al. [11] compared three different acetylation levels at the same mass loss level with untreated samples and found a significant upregulation in AlOx3 between high-level acetylated and untreated samples. This supports our findings, even though it cannot be decided with certainty that only the oxidative degradation phase was detected due to the sample design in Alfredsen et al. [11]. Beck et al. [13] also reported upregulation of AlOx2 and AlOx3 in acetylated samples as compared with untreated samples, at initial decay. They also found a significantly higher upregulation in the highest level of acetylated samples when looking at samples in early stages of decay, which is similar to our results [13], assuming that Beck et al. [13] only looked at mycelia in the non-enzymatic degradation stage. Ringman et al. [70] reported a small, but not significant, upregulation of AlOx3 in acetylated samples, which differs from our findings. In another study from Ringman et al. [76], an upregulation of $\mathrm{AlO} \times 3$ in modified samples as compared with untreated samples was seen, as well as in Schmöllerl et al. [69]. This indicates a higher investment in the production of $\mathrm{H}_{2} \mathrm{O}_{2}$ on modified samples as compared with untreated samples.

AC15 showed the lowest values of $\mathrm{CyOx}$ gene expression while the highest values were seen in AC20 [13]. Beck et al. [13] did not find an upregulation in CyOx in acetylated samples, except for the AC17 samples. The reason for these differences might be the different sample design. They also found mass loss in the AC21 samples, showing that the fungus had started the enzymatic degradation phase, which may be another reason for the differences in gene expression. CyOx functions as a catalysator to form acetate and oxalate in filamentous fungi. Enhanced oxalate production forms soluble Fe $\mathrm{F}^{2+}$-oxalate complexes needed for the Fenton reaction [82]. This could explain the high expression, especially in samples with high levels of acetylation [83].

R. placenta appears to downregulate the formation of QRD in samples with lower acetylation levels as compared with untreated samples and upregulates it to a level high than that of the untreated samples when growing on higher-level acetylated samples. These results indicate that only higher levels of acetylation induce upregulation of QRD as compared with untreated samples. This suggests that the R. placenta QRD could be involved in stress defense rather than in the reduction of chelators. The lower levels of gene expression in AC10 and AC15 could be explained by less stress, since the fungus is still able to degrade the wood. Ringman et al. [70] showed a significant upregulation of QRD in acetylated samples after two and 14 days as compared with untreated samples. The results for QRD gene expression during the initial decay phase differ from the results found in the present study [70], clearly demonstrating the importance of studying the exact function of the QRD found in $R$. placenta in comparison to the two QRD genes found in G. trabeum. Beck et al. [13] found no significant upregulation of QRD (BqR) between different harvesting points. Alfredsen et al. [11] observed an increase of QRD expression on treated samples with increasing incubation time which most likely is a result of the enzymatic degradation. 


\subsubsection{Downregulated Genes}

The downregulation of the genes Lac1, PQT, GlyD, and AlOx1 clearly shows that not all genes presumably involved in the non-enzymatic oxidative degradation are upregulated when $R$. placenta is growing on acetylated wood as compared with untreated wood. This leads to the assumption that the downregulated genes may not be as important for the non-enzymatic degradation as assumed or that the acetylation affects the regulation of the genes.

Significantly lower levels of Lac1 expression were shown, in this study, for acetylated samples as compared with untreated, which differs from previous studies. Ringman et al. [77] studied Lac1 on thermally modified wood as compared with untreated wood and no significant differences were shown between treatments and different mass loss levels. In addition, previously, no significant differences have been shown by Zhang et al. [47] for gene expression of Lac1 between oxidative and enzymatic degradation which could indicate that Lac1 does not play an important role during the non-enzymatic oxidative degradation phase or the expression is inhibited through acetylation. However, they found the highest activity for laccase in the hyphal front.

Clearly higher amounts of PQT were found in untreated samples; downregulation in AC10 and further downregulation in AC15 seem to show a tendency. However, levels of PQT expression were higher in AC20, which does not follow any trendline. Since the differences in expression levels between the treatments in this study do not show any clear trends, they are difficult to interpret. The downregulation of PQT in acetylated samples seen in our study, may be due to the fact that this gene may not be involved in oxidative wood degradation after all. On the basisof its sequence, it was proposed to be a quinate transporter [58], however, it is also possible that it is a sugar transporter [59]. Ringman et al. [76] did not find significant differences in expression of PQT between treatments or time points during the non-enzymatic degradation phase but an induction of PQT was seen at 3\% mass loss. The results from Ringman et al. [76] indicate that PQT is not induced before the enzymatic degradation phase.

Expression levels of GlyD were significantly lower in all treated samples as compared with untreated. AC10 showed the lowest expression levels and gene expression in AC15 samples was upregulated as compared with the other two treatment levels. Since GlyD levels were lower in AC20 samples as compared with AC15 samples, a clear trend cannot be observed. No significant differences were shown for GlyD in Beck et al. [13], except at the first harvesting point, where untreated samples showed higher expression of GlyD as compared with all levels of acetylation. However, Munir et al. [84] suggested that the major enzyme involved in oxalate production in wood rotting basidiomycetes could be oxaloacetase, which makes the interpretation of our GlyD results difficult. Determination of the total oxalic acid production for comparison of the amounts of different treatments and treatment levels would be a useful goal for further research [85].

In this study, a downregulation of $\mathrm{AlOx} 1$ was seen for $\mathrm{AC} 20$, and for $\mathrm{AC} 10$ markedly lower rates as compared with untreated samples were seen. However, AC15 behaved differently, since there was no significant difference between expression levels of $\mathrm{AC} 15$ as compared with untreated samples in this study. Beck et al. [13] reported a downregulation of AlOx1 in AC17 and AC21 samples as compared with AC10 and untreated samples. The results imply that AlOx1 does not serve the same purpose as $\mathrm{AlOx} 2$ and $\mathrm{AlOx} 3$.

\subsubsection{Effect of Acetylation on Overall Gene Expression}

In this study, not all genes previously proposed to be involved in oxidative processes were upregulated in acetylated samples as compared with untreated samples. Instead, some were associated with much lower expression levels in acetylated samples as compared with untreated samples. Because of a high number of replicates $(n \geq 11)$ and the high significance of the results, these findings can be considered reliable.

Zhang et al. [86] suggested that the shift between non-enzymatic and enzymatic wood degradation is mediated by cellobiose, which is formed through degradation of cellulose. In wood not experiencing 
mass loss, the levels of cellobiose are assumed to be low, keeping the expression of the genes in the enzymatic degradation phase at a low level. However, the absence of glucose, upregulates the expression of non-enzymatic genes [86]. Therefore, it is assumed, in modified wood, that there is a general upregulation of the genes involved in the non-enzymatic degradation phase, since the fungus is struggling to degrade it. Previous studies have shown that $R$. placenta both up- and downregulates the expression of some genes assumed to be involved in oxidative degradation processes when growing on modified wood, which is in accordance with our results [68-70]. These results, together with previously published gene expression studies on modified wood $[11,69,70,75,76,78,79]$, imply that there might be mechanisms in the regulation of the non-enzymatic degradation in addition to the cellobiose switch proposed by Zhang et al. [86] that are important also in untreated wood. However, it should be noted that in modified wood, degradation products, such as cellobiose, presumably will be modified as well during the wood modification process, which may affect their function as gene expression regulators. Hence, it should be noted that in acetylated wood, the degradation products might look different from the degradation products in untreated wood since they come from wood constituents that were acetylated.

The expression of genes involved in the non-enzymatic degradation phase appeared to be enhanced group-wise according to an increasing level of acetylation. An upregulation of GOx2 and Cro1 (involved in the $\mathrm{H}_{2} \mathrm{O}_{2}$ - production) was seen in $\mathrm{AC} 10$ as compared with untreated wood. In $\mathrm{AC} 15$, the same two genes were upregulated including two more, also involved in the production of $\mathrm{H}_{2} \mathrm{O}_{2}, \mathrm{AlOx} 2$, and AlOx3. In AC20, in addition to GOx2, Cro1, AlOx2, and AlOx3, also CyOx and QRD (both involved in the oxalic acid production) were upregulated. Perhaps the fungus is trying to increase the output of the Fenton reaction by increasing the input of $\mathrm{H}_{2} \mathrm{O}_{2}$. Perhaps this works for $\mathrm{AC} 10$ and $\mathrm{AC} 15$, and more sugars are diffusing out into the lumen, but it does not seem to be the case for AC20. Here the fungus must do something more, so it additionally upregulates the production of oxalic acid, trying to set more iron free, and thereby increasing the output of the Fenton reaction. It is possible that upregulating the genes involved in $\mathrm{H}_{2} \mathrm{O}_{2}$ production presents the lowest "cost" for the fungus and that it is a more direct way to control the Fenton reaction. However, when that does not work, other measures have to be taken.

A clear downregulation of at least some genes, presumably involved in the non-enzymatic oxidative degradation mechanism, implies that the downregulated genes either do not have the function they were assumed to have or that they do not play an important role during the first degradation step. Comparisons with previous studies proved difficult, due to the differences in sample designs. A complete picture of all transcribed genes (transcriptome sequencing) during the early stages of decay and a comparison between untreated samples and treated samples would be of great interest. Useful data on gene expression levels during enzymatic degradation from the same wood wafers for comparison would also be valuable.

\section{Conclusions}

In this study the gene expression of $10 \mathrm{R}$. placenta genes, presumed to be important in the non-enzymatic degradation phase, were studied in untreated and wood acetylated to three different levels. The expression of the genes involved in the non-enzymatic degradation phase appeared to be enhanced group-wise according to an increasing level of acetylation. R. placenta seemed to first increase the output of the Fenton reaction by increasing the input of $\mathrm{H}_{2} \mathrm{O}_{2}$, trying to establish a satisfying level of degradation, and when this was not possible, the production of oxalic acid was enhanced. Highly interesting is the fact that even though growth and degradation were not inhibited in AC10 samples, results on gene expression showed a relatively strong reaction of the fungus. Furthermore, the results of this study show that $R$. placenta upregulates parts of the genes involved in non-enzymatic oxidative degradation when growing on acetylated samples as compared with untreated wood, especially on higher levels of acetylation. However, only six of the 10 genes are as important for the non-enzymatic degradation phase as previously assumed. The results imply, for example, that AlOx1 does not 
serve the same purpose as $\mathrm{AlOx} 2$ and $\mathrm{AlOx3}$. This confirms previous findings by Beck et al. [13]. Furthermore, the results indicate that only higher levels of acetylation induce upregulation of QRD as compared with untreated samples. This suggests that the R. placenta QRD may be involved in stress defense rather than in the reduction of chelators. Highlighting the importance of finding the true function of the QRD gene in R. placenta. The results from this study, together with previously published gene expression studies on modified wood $[11,69,70,75,76,78,79]$, imply that there might be mechanisms in the regulation of the non-enzymatic degradation in addition to the cellobiose switch proposed by Zhang et al. [86] in both untreated and modified wood. It would be interesting to apply this method to other modification methods, such as furfurylated and thermally-modified wood. Further research on the whole transcriptome including both the non-enzymatic and the enzymatic degradation phase would be of great interest for an increased understanding of the wood degrading capacities of R. placenta.

Author Contributions: Conceptualization, M.K., A.P., and R.R.; methodology, M.K., A.P., and R.R.; measurements, M.K.; writing—original draft preparation, M.K., A.P., and R.R.; writing—review and editing, M.K., A.P., and R.R.; visualization, M.K.

Funding: This research was funded by the Swedish Research Council FORMAS, 942-2015-530.

Acknowledgments: The authors gratefully acknowledge financial support from The Swedish Research Council Formas 942-2015-530.

Conflicts of Interest: The authors declare no conflict of interest. The funders had no role in the design of the study; in the collection, analyses, or interpretation of data; in the writing of the manuscript, or in the decision to publish the results.

\section{References}

1. Rowell, R.M. Wood Chemistry and Wood Composites; Rowell, R.M., Ed.; Taylor \& Francis: Boca Raton, FL, USA, 2005; p. 703. [CrossRef]

2. Huß, W.; Krötsch, S. Energieeffizientes Sanieren und Bauen mit Holz. LWF Aktuell 2013, 97, 4.

3. Jakes, J.E.; Arzola, X.; Bergman, R.; Ciesielski, P.; Hunt, C.G.; Rahbar, N.; Tshabalala, M.; Wiedenhoeft, A.C.; Zelinka, S.L. Not Just Lumber-Using Wood in the Sustainable Future of Materials, Chemicals, and Fuels. JOM 2016, 68, 10. [CrossRef]

4. Bergman, R.; Puettmann, M.; Taylor, A.; Skog, K. The Carbon Impacts of Wood Products. For. Prod. J. 2014, 64, 13. [CrossRef]

5. Zabel, R.A.; Morrell, J.J. Wood Microbiology: Decay and Its Prevention; Academic Press: San Diego, CA, USA, 1992.

6. Eaton, R.; Hale, M. Decay, Pests and Protection; Chapman \& Hall: Cambridge, UK, 1993.

7. Lebow, S. Alternatives to Chromated Copper Arsenate (CCA) for Residential Construction. In Proceedings of the Environmental Impacts of Preservative-Treated Wood, Orlando, FL, USA, 8-10 February 2004; p. 12.

8. Hill, C. Wood Modification: Chemical, Thermal and other Processes; Stevens, C.V., Ed.; John Wiley and Sons, Ltd.: Hoboken, NJ, USA, 2006.

9. Townsend, T.; Dubey, B.; Tolaymat, T.; Solo-Gabriele, H. Preservative leaching from weathered CCA-treated wood. J. Environ. Manag. 2005, 75, 105-113. [CrossRef]

10. Mantanis, G.I. Chemical modification of wood by acetylation or furfurylation: A review of the present scaled-up technologies. Bioresources 2017, 12, 12. [CrossRef]

11. Alfredsen, G.; Pilgård, A.; Fossdal, C.G. Characterisation of Postia placenta colonisation during 36 weeks in acetylated southern yellow pine sapwood at three acetylation levels including genomic DNA and gene expression quantification of the fungus. Holzforschung 2016, 70, 11. [CrossRef]

12. Hosseinpourpia, R.; Mai, C. Mode of action of brown rot decay resistance of acetylated wood: Resistance to Fenton's reagent. Wood Sci. Technol. 2016, 50, 413-426. [CrossRef]

13. Beck, G.; Hegnar, O.A.; Fossdal, C.G.; Alfredsen, G. Acetylation of Pinus radiata delays hydrolytic depolymerisation by the brown-rot fungus Rhondonia placenta. Int. Biodeterior. Biodegrad. 2018, 135, 39-52. [CrossRef] 
14. Engelund, E.; Thygesen, L.G.; Svensson, S.; Hill, C. A critical discussion of the physics of wood-water interactions. Wood Sci. Technol. 2013, 47, 21. [CrossRef]

15. Popescu, C.-M.; Hill, C.A.S.; Curling, S.; Ormondroyd, G.; Xie, Y. The water vapour sorption behaviour of acetylated birch wood: How acetylation affects the sorption isotherm and accessible hydroxyl content. J. Mater. Sci. 2014, 49, 2362-2371. [CrossRef]

16. Beck, G.; Thybring, E.; Thygesen, L.; Hill, C. Characterization of moisture in acetylated and propionylated radiata pine using low-field nuclear magnetic resonance (LFNMR) relaxometry. Holzforschung 2017. [CrossRef]

17. Stamm, A.J.; Baechler, R.H. Decay resistance and dimensional stability of five modified woods. For. Prod. J. $1960,10,22-26$.

18. Ibach, R.E.; Rowell, R.M. Improvements in Decay Resistance Based on Moisture Exclusion. Mol. Cryst. Liq. Cryst. Sci. Technol. Sect. A Mol. Cryst. Liq. Cryst. 2000, 353, 23-33. [CrossRef]

19. Larsson Brelid, P.; Simonson, R.; Bergman, Ö.; Nilsson, T. Resistance of acetylated wood to biological degradation. Holz Als Roh- Und Werkst. 2000, 58, 331-337. [CrossRef]

20. Hill, C. Why does acetylation protect wood from microbiological attack? Wood Mater. Sci. Eng. 2009, 4, 37-45. [CrossRef]

21. Papadopoulos, A.N.; Hill, C.A.S. The biological effectiveness of wood modified with linear chain carboxylic acid anhydrides against Coniophora puteana. Holz Als Roh- Und Werkst. 2002, 60, 329-332. [CrossRef]

22. Jakes, J.; Plaza, N.; Stone, D.S.; Hunt, C.; Glass, S.; Zelinka, S. Mechanism of Transport Through Wood Cell Wall Polymers. J. For. Prod. Ind. 2013, 2, 10-13.

23. Xie, Y.; Xiao, Z.; Mai, C. Degradation of chemically modified Scots pine (Pinus sylvestris L.) with Fenton reagent. Holzforschung 2015, 69, 153. [CrossRef]

24. Zelinka, S.L.; Ringman, R.; Pilgård, A.; Thybring, E.E.; Jakes, J.E.; Richter, K. The role of chemical transport in the brown-rot decay resistance of modified wood AU - Zelinka, S.L. Int. Wood Prod. J. 2016, 7, 66-70. [CrossRef]

25. Ringman, R.; Pilgård, A.; Brischke, C.; Richter, K. Mode of action of brown rot decay resistance in modified wood: A review. Holzforschung 2014, 68, 239. [CrossRef]

26. Hunt, C.; Zelinka, S.; Frihart, C.; Lorenz, L.; Yelle, D.; Gleber, S.-C.; Vogt, S.; Jakes, J.E. Acetylation increases relative humidity threshold for ion transport in wood cell walls-A means to understanding decay resistance. Int. Biodeterior. Biodegrad. 2018, 133, 230-237. [CrossRef]

27. Zelinka, S.; Glass, S.; Stone, D. A percolation model for electrical conduction in wood with implications for wood-water relations. Wood Fiber Sci. J. Soc. Wood Sci. Technol. 2008, 40, 544-552.

28. Zelinka, S.L.; Gleber, S.C.; Vogt, S.; López, G.M.R.; Jakes, J.E. Threshold for ion movements in wood cell walls below fiber saturation observed by X-ray fluorescence microscopy (XFM). Holzforschung 2015, 69, 441-448. [CrossRef]

29. Kirk, P.M.; Cannon, P.F.; Minter, D.W.; Stalpers, J.A. Dictionary of the Funghi, 10th ed.; CAB International: Wallingford, UK, 2008.

30. Eriksson, K.; Blanchette, R.A.; Ander, P. Microbial and Enzymatic Degradation of Wood and Wood Components; Springer: Berlin, Germany, 1990.

31. Blanchette, R. Delignification by Wood-Decay Fungi. Annu. Rev. Phytopathol. 1991, 29, 18. [CrossRef]

32. Daniel, G. Use of electron microscopy for aiding our understanding of wood biodegradation. FEMS Microbiol. Rev. 1994, 13, 199-233. [CrossRef]

33. Riley, R.; Salamov, A.A.; Brown, D.W.; Nagy, L.G.; Floudas, D.; Held, B.W.; Levasseur, A.; Lombard, V.; Morin, E.; Otillar, R.; et al. Extensive sampling of basidiomycete genomes demonstrates inadequacy of the white-rot/brown-rot paradigm for wood decay fungi. Proc. Natl. Acad. Sci. USA 2014, 111, 9923-9928. [CrossRef]

34. Liese, W. Ultrastructural Aspects of Woody Tissue Disintegration. Annu. Rev. Phytopathol. 1970, 8, $231-258$. [CrossRef]

35. Martin, F. Fair Trade in the Underworld: The Ectomycorrhizal Symbiosis. In Biology of the Fungal Cell; Howard, R.J., Gow, N.A.R., Eds.; Springer: Berlin/Heidelberg, Germany, 2007; pp. 291-308. [CrossRef]

36. Schmidt, O. Indoor wood-decay basidiomycetes: Damage, causal fungi, physiology, identification and characterization, prevention and control. Mycol. Prog. 2007, 6, 261. [CrossRef] 
37. Alfredsen, G.; Solheim, H.; Mohn Jenssen, K. Evaluation of decay fungi in Norwegian buildings. In Proceedings of the IRG Annual Meeting, IRG/WP 09-10701, Bangalore, India, 24-28 April 2015; p. 11.

38. Vanden Wymelenberg, A.; Gaskell, J.; Mozuch, M.; Sabat, G.; Ralph, J.; Skyba, O.; Mansfield, S.D.; Blanchette, R.A.; Martinez, D.; Grigoriev, I.; et al. Comparative Transcriptome and Secretome Analysis of Wood Decay Fungi Postia placenta and Phanerochaete chrysosporium. Appl. Environ. Microbiol. 2010, 76, 3599-3610. [CrossRef]

39. Goodell, B. Brown-Rot Fungal Degradation of Wood: Our Evolving View. In Wood Deterioration and Preservation; American Chemical Society: Washington, DC, USA, 2003; Volume 845, pp. 97-118.

40. Filley, T.R.; Cody, G.D.; Goodell, B.; Jellison, J.; Noser, C.; Ostrofsky, A. Lignin demethylation and polysaccharide decomposition in spruce sapwood degraded by brown rot fungi. Org. Geochem. 2002, 33, 111-124. [CrossRef]

41. Curling, S.F.; Clausen, C.A.; Winandy, J.E. Relationships between mechanical properties, weight loss, and chemical composition of wood during incipient brown-rot decay. For. Prod. J. 2002, 52, 34-39.

42. Martínez, Á.T.; Speranza, M.; Ruiz-Dueñas, F.J.; Ferreira, P.; Camarero, S.; Guillén, F.; Martínez, M.J.; Gutiérrez, A.; Del Río, J.C. Biodegradation of lignocellulosics: Microbial, chemical, and enzymatic aspects of the fungal attack of lignin. Int. Microbiol. 2005, 8, 195-204. [PubMed]

43. Niemenmaa, O.; Uusi-Rauva, A.; Hatakka, A. Demethoxylation of [O14CH3]-labelled lignin model compounds by the brown-rot fungi Gloeophyllum trabeum and Poria (Postia) placenta. Biodegradation 2007, 19, 555. [CrossRef] [PubMed]

44. Arantes, V.; Goodell, B. Current Understanding of Brown-Rot Fungal Biodegradation Mechanisms: A Review. In Deterioration and Protection of Sustainable Biomaterials; American Chemical Society: Washington, DC, USA, 2014; Volume 1158, pp. 3-21.

45. Baldrian, P.; Valášková, V. Degradation of cellulose by basidiomycetous fungi. FEMS Microbiol. Rev. 2008, 32, 501-521. [CrossRef]

46. Arantes, V.; Jellison, J.; Goodell, B. Peculiarities of brown-rot fungi and biochemical Fenton reaction with regard to their potential as a model for bioprocessing biomass. Appl. Microbiol. Biotechnol. 2012, 94, 323-338. [CrossRef]

47. Zhang, J.; Presley, G.N.; Hammel, K.E.; Ryu, J.-S.; Menke, J.R.; Figueroa, M.; Hu, D.; Orr, G.; Schilling, J.S. Localizing gene regulation reveals a staggered wood decay mechanism for the brown rot fungus Postia placenta. Proc. Natl. Acad. Sci. USA 2016, 113, 10968-10973. [CrossRef]

48. Eastwood, D.C.; Floudas, D.; Binder, M.; Majcherczyk, A.; Schneider, P.; Aerts, A.; Asiegbu, F.O.; Baker, S.E.; Barry, K.; Bendiksby, M.; et al. The Plant Cell Wall-Decomposing Machinery Underlies the Functional Diversity of Forest Fungi. Science 2011, 333, 762-765. [CrossRef]

49. Goodell, B.; Jellison, J.; Liu, J.; Daniel, G.; Paszczynski, A.; Fekete, F.; Krishnamurthy, S.; Jun, L.; Xu, G. Low molecular weight chelators and phenolic compounds isolated from wood decay fungi and their role in the fungal biodegradation of wood1This is paper 2084 of the Maine Agricultural and Forest Experiment Station.1. J. Biotechnol. 1997, 53, 133-162. [CrossRef]

50. Paszczynski, A.; Crawford, R.; Funk, D.; Goodell, B. De novo synthesis of 4,5-dimethoxycatechol and 2, 5-dimethoxyhydroquinone by the brown rot fungus Gloeophyllum trabeum. Appl. Environ. Microbiol. 1999, 65, 674-679.

51. Jensen, K.A.; Houtman, C.J.; Ryan, Z.C.; Hammel, K.E. Pathways for Extracellular Fenton Chemistry in the Brown Rot Basidiomycete Gloeophyllum trabeum. Appl. Environ. Microbiol. 2001, 67, 2705-2711. [CrossRef]

52. Fenton, H. Oxidation of tartaric acid in the presence of iron. J. Chem. Soc. Trans. 1894, 65, 12. [CrossRef]

53. Goodell, B.; Zhu, Y.; Kim, S.; Kafle, K.; Eastwood, D.C.; Daniel, G.; Jellison, J.; Yoshida, M.; Groom, L.; Pingali, S.V.; et al. Modification of the nanostructure of lignocellulose cell walls via a non-enzymatic lignocellulose deconstruction system in brown rot wood-decay fungi. Biotechnol. Biofuels 2017, 10, 15. [CrossRef] [PubMed]

54. Martinez, D.; Challacombe, J.; Morgenstern, I.; Hibbett, D.S.; Schmoll, M.; Kubicek, C.P.; Ferreira, P.; Ruiz-Dueñas, F.J.; Martinez, A.T.; Kersten, P.; et al. Genome, transcriptome, and secretome analysis of wood decay fungus Postia placenta supports unique mechanisms of lignocellulose conversion. Proc. Natl. Acad. Sci. USA 2009, 106, 6. [CrossRef] [PubMed] 
55. Jensen, K.; Ryan, Z.; Marty, A.; Cullen, D.; Hammel, K.E. An NADH: Quinone Oxidoreductase Active during Biodegradation by the Brown-Rot Basidiomycete Gloeophyllum trabeum. Appl. Environ. Microbiol. 2002, 68, 2699-2703. [CrossRef] [PubMed]

56. Qi, W.; Jellison, J. Characterization of a transplasma membrane redox system of the brown rot fungus Gloeophyllum trabeum. Int. Biodeterior. Biodegrad. 2004, 53, 37-42. [CrossRef]

57. Cohen, R.; Suzuki, M.R.; Hammel, K.E. Differential stress-induced regulation of two quinone reductases in the brown rot basidiomycete Gloeophyllum trabeum. Appl. Environ. Microbiol. 2004, 70, 324-331. [CrossRef] [PubMed]

58. Mueckler, M.; Caruso, C.; Baldwin, S.A.; Panico, M.; Blench, I.; Morris, H.R.; Allard, W.J.; Lienhard, G.E.; Lodish, H.F. Sequence and structure of a human glucose transporter. Science 1985, 229, 941. [CrossRef]

59. Yan, N. Structural Biology of the Major Facilitator Superfamily Transporters. Annu. Rev. Biophys. 2015, 44, 257-283. [CrossRef]

60. Wardman, P. Reduction Potentials of One-Electron Couples Involving Free Radicals in Aqueous Solution. J. Phys. Chem. Ref. Data 1989, 18, 1637-1755. [CrossRef]

61. Wei, D.; Houtman, C.J.; Kapich, A.; Hunt, C.; Cullen, D.; Hammel, K.E. Laccase and Its Role in Production of Extracellular Reactive Oxygen Species during Wood Decay by the Brown Rot Basidiomycete Postia placenta. Appl. Environ. Microbiol. 2010, 76, 2091-2097. [CrossRef]

62. Floudas, D.; Binder, M.; Riley, R.; Barry, K.; Blanchette, R.A.; Henrissat, B.; Martínez, A.T.; Otillar, R.; Spatafora, J.W.; Yadav, J.S.; et al. The Paleozoic Origin of Enzymatic Lignin Decomposition Reconstructed from 31 Fungal Genomes. Science 2012, 336, 1715-1719. [CrossRef] [PubMed]

63. Levasseur, A.; Drula, E.; Lombard, V.; Coutinho, P.M.; Henrissat, B. Expansion of the enzymatic repertoire of the CAZy database to integrate auxiliary redox enzymes. Biotechnol. Biofuels 2013, 6, 41. [CrossRef] [PubMed]

64. Takao, S. Organic Acid Production by Basidiomycetes. Appl. Microbiol. 1965, 13, 732. [PubMed]

65. Akamatsu, Y.; Shimada, M. Partial purification and characterization of glyoxylate oxidase from the brown-rot basidiomycete Tyromyces palustris. Phytochemistry 1994, 37, 649-653. [CrossRef]

66. Munir, E.; Yoon, J.-J.; Tokimatsu, T.; Hattori, T.; Shimada, M. New role for glyoxylate cycle enzymes in wood-rotting basidiomycetes in relation to biosynthesis of oxalic acid. J. Wood Sci. 2001, 47, 368-373. [CrossRef]

67. Tokimatsu, T.; Nagai, Y.; Hattori, T.; Shimada, M. Purification and characteristics of a novel cytochrome c dependent glyoxylate dehydrogenase from a wood-destroying fungus Tyromyces palustris 1. FEBS Lett. 1998, 437, 117-121. [CrossRef]

68. Pilgård, A.; Alfredsen, G.; Fossdal, C.G.; Long, I.C.J. The effects of acetylation on the growth of Postia placenta over 36 weeks. In Proceedings of the IRG Annual Meeting, Kuala Lumpur, Malaysia, 6-10 May 2012. IRG/WP 12-40589.

69. Schmöllerl, B.; Alfredsen, G.; Fossdal, C.G.; Westin, M.; Steitz, A. Molecular investigation of Postia placenta growing in modified wood. In Proceedings of the IRG Annual Meeting, IRG/WP 11-10756, Queenstown, New Zealand, 8-12 May 2018; p. 10.

70. Ringman, R.; Pilgård, A.; Richter, K. Effect of wood modification on gene expression during incipient Postia placenta decay. Int. Biodeterior. Biodegrad. 2014, 86, 86-91. [CrossRef]

71. Ringman, R.; Pilgård, A.; Brischke, C.; Windeisen, E.; Richter, K. Incipient brown rot decay in modified wood: Patterns of mass loss, structural integrity, moisture and acetyl content in high resolution. Int. Wood Prod. J. 2017. [CrossRef]

72. Bravery, A.F. A miniaturised wood-block test for the rapid evaluation of preservative fungicides. In Screening Techniques for Potential Wood Preservative Chemicals. Proceedings of the a Special Seminar Held in Association with the 10th Annual Meeting of IRG, Peebles, UK, 18-22 September 1978; IRG: Washington, DC, USA, 1978.

73. Alfredsen, G.; Pilgård, A. Postia placenta decay of acetic anhydride modified wood-Effect of leaching. Wood Mater. Sci. Eng. 2014. [CrossRef]

74. Schilling, J.S.; Duncan, S.M.; Presley, G.N.; Filley, T.R.; Jurgens, J.A.; Blanchette, R.A. Colocalizing incipient reactions in wood degraded by the brown rot fungus Postia placenta. Int. Biodeterior. Biodegrad. 2013, 83, 56-62. [CrossRef] 
75. Alfredsen, G.; Ringman, R.; Pilgård, A.; Fossdal, C.G. New insight regarding mode of action of brown rot decay of modified wood based on DNA and gene expression studies: A review. Int. Wood Prod. J. 2015, 6, 5-7. [CrossRef]

76. Ringman, R.; Pilgård, A.; Kölle, M.; Richter, K. Expression patterns of Postia placenta genes involved in the chelator mediated Fenton degradation in modified wood. In Proceedings of the European Conference on Wood Modification, Arnhem, The Netherlands, 17-18 September 2019; p. 3.

77. Ringman, R.; Pilgård, A.; Kölle, M.; Brischke, C.; Richter, K. Effects of thermal modification on Postia placenta wood degradation dynamics: Measurements of mass loss, structural integrity and gene expression. Wood Sci. Technol. 2016, 50, 385-397. [CrossRef]

78. Alfredsen, G.; Fossdal, C.G.; Nahy, N.E.; Jellison, J.; Goodell, B. Furfurylated wood: Impact on Postia placenta gene expression and oxalate crystal formation. Holzforschung 2016, 70, 16. [CrossRef]

79. Pilgård, A.; Schmöllerl, B.; Risse, M.; Fossdal, C.G.; Alfredsen, G. Profiling Postia placenta colonisation in modified wood-microscopy, DNA quantification and gene expression. In Proceedings of the Wood Science and Engineering Conference, Copenhagen, Denmark, 17-18 September 2019.

80. Salame, T.M.; Knop, D.; Levinson, D.; Yarden, O.; Hadar, Y. Redundancy among manganese peroxidases in Pleurotus ostreatus. Appl. Environ. Microbiol. 2013, 79, 2405. [PubMed]

81. Ringman, R.; Beck, G.; Pilgård, A. The Importance of Moisture for Brown Rot Degradation of Modified Wood: A Critical Discussion. Forests 2019, 10, 522. [CrossRef]

82. Arantes, V.; Qian, Y.; Milagres, A.M.F.; Jellison, J.; Goodell, B. Effect of $\mathrm{pH}$ and oxalic acid on the reduction of $\mathrm{Fe} 3+$ by a biomimetic chelator and on Fe3+ desorption/adsorption onto wood: Implications for brown-rot decay. Int. Biodeterior. Biodegrad. 2009, 63, 478-483. [CrossRef]

83. Narayanan, B.C.; Niu, W.; Han, Y.; Zou, J.; Mariano, P.S.; Dunaway-Mariano, D.; Herzberg, O. Structure and function of PA4872 from Pseudomonas aeruginosa, a novel class of oxaloacetate decarboxylase from the PEP mutase/isocitrate lyase superfamily. Biochemistry 2008, 47, 167-182. [CrossRef]

84. Munir, E.; Yoon, J.; Tokimatsu, T.; Hattori, T.; Shimada, M. A physiological role for oxalic acid biosynthesis in the wood-rotting basidiomycete Fomitopsis palutris. Proc. Natl. Acad. Sci. USA 2001, 98, 11126-11130. [CrossRef]

85. Schilling Jonathan, S.; Jellison, J. High-performance liquid chromatographic analysis of soluble and total oxalate in Ca- and Mg-amended liquid cultures of three wood decay fungi. Holzforschung 2004, 58, 682. [CrossRef]

86. Zhang, J.; Schilling, J. Role of carbon source in the shift from oxidative to hydrolytic wood decomposition by Postia placenta. Fungal Genet. Biol. 2017, 106. [CrossRef] 